\title{
RESEARCH PAPER \\ INSECTICIDE HANDLING IN COCOA PRODUCTION IN FOUR REGIONS IN GHANA
}

\author{
A. K. Antwi-Agyakwa ${ }^{1}$, E. A. Osekre ${ }^{1}$, K. D. Ninsin ${ }^{3}$ and R. Adu-Acheampong ${ }^{2}$ \\ ${ }^{I}$ Department of Crop and Soil Sciences, Faculty of Agriculture, KNUST, Kumasi \\ akuakonaduantwi@gmail.com \\ ${ }^{2}$ Entomology Division, Cocoa Research Institute of Ghana, Ghana \\ r.aduacheampong@yahoo.co.uk \\ ${ }^{3}$ CSIR-Animal Research Institute, Accra, Ghana \\ kdninsin@hotmail.com \\ Corresponding author: osek652001@yahoo.co.uk
}

\begin{abstract}
Management of insect pests of cocoa (Theobroma cacao L.) using insecticides began in 1950 and has since gone through various programmes with concomitant challenges and successes. Presently Imidacloprid (Confidor $\left.{ }^{\circledR}\right)$, Bifenthrin (Akatemaster $\left.{ }^{\circledR}\right)$ and Thiamethoxam (Actara $\left.{ }^{\circledR}\right)$ are recommended by Ghana Cocoa Board (COCOBOD) for the management of insect pests. A survey was conducted in the Ashanti, Eastern, Volta and Western Regions of Ghana using questionnaires and farm visits of 147 cocoa farmers' fields to gather information on the characteristics of the farmers and insecticide handling and use by respondents. The survey showed that males dominated cocoa farming (72.7\%) and most of them aged between 50 and 60 years. About 44\% have had basic education whilst $37.5 \%$ of them belonged to farmer based organizations. About $52.8 \%$ of the farmers own motorized mistblower but $47.2 \%$ of the farmers use knapsack in the absence of a mistblower. About $44.8 \%$ do their own spray application whereas $55.2 \%$ hire labour. About $60.9 \%$ of the population across the regions read the label on the insecticides before application. A few (31.6\%) of the respondents put on the full personal protective costume during insecticide application and $21.9 \%$ do not use any protection. There was a positive correlation between farmers' membership of farmer-based organisation and the costume-wearing farmers in the Ashanti, Eastern and Volta Regions and it was significant in the Ashanti region. It is recommended that training and monitoring programmes be organized for farmers on the need to handle pesticides properly for personal and environmental safety and consumer benefit.
\end{abstract}

Keywords: Insecticides, pest management, cocoa farmers, safety

\section{INTRODUCTION}

Cocoa, Theobroma cacao L. is an important cash crop and contributes to about $28 \%$ of Ghana's foreign exchange earnings and $63 \%$ of agricultural exports (Anim-Kwapong and Frim- pong, 2006). Cocoa mirids commonly called capsids have been recognised as serious pests since 1908 (Dungeon, 1910) due to their devastating effect on cocoa production. Mirid control has for more than a century been based on 


\section{Antwi-Agyakwa et al.}

chemical application but the adoption rate by cocoa farmers has been very low due to cost and other institutional constraints (Padi et al., 2001). To address the issues of poor pests and diseases control by farmers, the Government of Ghana in 2001 introduced a nation-wide Cocoa Diseases and Pests Control Programme (CODAPEC) (commonly referred to as mass spraying) with the view to increasing cocoa output (Dormon et al., 2007) and creating jobs in rural communities. Spraying of the insecticide is calendar-based and done four times a year from the period of August to December, leaving out November for harvesting and to ensure that the treatment coincides with the main period of mirid population increase, which is between August and November (AduAcheampong et al., 2007). Satisfactory mirid control is achieved with insecticide application. Pesticides misuse and mishandling is known to occur among farmers in Ghana. Consequences of pesticide abuse and misuse, improper application and failure to adopt full research recommendations (Dormon et al., 2007) include resistance of insect pest populations to insecticides, pest resurgence and pesticide residues in food and feed. This study was therefore undertaken to gather information on insecticide handling and use by cocoa farmers in the Ashanti, Eastern, Volta and Western Regions of Ghana with the view to using the information gathered from the study as a guide to suggest remedial measures against the worsening appearance of the negative effects of the insecticides used by the farmers.

\section{MATERIALS AND METHODS}

The study was undertaken in 2012 and involved questionnaire administration and farm visits. In all, 147 cocoa farmers comprising 36 from Ashanti, 30 from Eastern, 31 from Volta and 50 from Western Regions of Ghana were covered. Respondents were selected at random in each town visited using coded numbers which were picked by the respondents through balloting. Thus, respondents who picked coded numbers from the balloting were selected for the study. The questionnaire was structured mostly with closed-ended questions and a few open ended ones and administered using one-on-one interviews. The closed-ended questions enabled the exact information being sought to be collected for quantitative analysis, whilst the open ended ones gave the respondents more room to clarify certain responses provided. Data taken on the characteristics of respondents included gender, marital status, number of dependents, educational level and number of years in farming. Other data were size of cocoa farm, farm ownership, output of farmer, membership of farmer -based organization, source of farm inputs, production constraints, types of insecticides used, frequency of insecticide application, use of personal protective equipment, re-entry period of pesticides and knowledge of expiry date of pesticides.

\section{Data processing and statistical analysis}

The questionnaires were coded by assigning a unique abbreviation to each question. The Statistical Package for Social Sciences (SPSS) software (release 20.0.0, IBM Corporation and its Licensors 1989, 2011) was used for the analysis of the data. The strength of a linear association between two variables was estimated using the Pearson Correlation (r) and significance level was tested at $95 \%$.

\section{RESULTS}

\section{Characteristics of respondents}

Table 1 summarises the general characteristics of the respondents in the study. The mean age was 60 years; a majority $(72.7 \%)$ of the respondents were males and a majority $(88.9 \%)$ were married. Only $24.6 \%$ of the respondents had no formal education with the highest level of illiteracy, i.e. $34 \%$, recorded in Western region. Volta region had $3.2 \%$ of farmers having tertiary education. A good number of farmers represented by $44.4 \%, 46.6 \%, 54.9 \%$ and $46 \%$ in the Ashanti, Eastern, Volta and Western Regions, respectively had only basic education. Quite a good number of farmers (i.e. 31.4\%, 53.3\%, $35.5 \%$ and $30 \%$ in the Ashanti, Eastern, Volta and Western regions, respectively) were members of farmer-based organisations. Examples 
Insecticide handling by cocoa farmers ...

Table 1: Characteristics of cocoa farmers in four regions of Ghana

\begin{tabular}{|c|c|c|c|c|c|}
\hline \multirow[t]{2}{*}{ Variable } & \multicolumn{4}{|c|}{$\begin{array}{l}\text { Mean } \\
\text { or \% }\end{array}$} & \multirow[b]{2}{*}{ Mean } \\
\hline & Ashanti & Eastern & Volta & Western & \\
\hline Age of Farmer (years) & 66.0 & 57.27 & 49.84 & 50.58 & 60.00 \\
\hline Sex (male) & 49.58 & 66.70 & 96.80 & 78.00 & 72.77 \\
\hline Marital status (Married) & 88.90 & 86.70 & 90.30 & 90.00 & 88.98 \\
\hline Illiterates & 22.20 & 13.30 & 29.00 & 34.00 & 24.63 \\
\hline $\begin{array}{l}\text { Membership of Farmer-based } \\
\text { organisation (Yes) }\end{array}$ & 31.40 & 53.30 & 35.50 & 30.00 & 37.55 \\
\hline
\end{tabular}

Table 2: Re-entry period of farmers' in four regions of Ghana

\begin{tabular}{lccrcr}
\hline Variable & $\begin{array}{c}\text { Ashanti } \\
(\boldsymbol{\%})\end{array}$ & $\begin{array}{c}\text { Eastern } \\
(\boldsymbol{\%})\end{array}$ & $\begin{array}{c}\text { Volta } \\
(\boldsymbol{\%})\end{array}$ & $\begin{array}{c}\text { Western } \\
(\boldsymbol{\%})\end{array}$ & $\begin{array}{c}\text { Average } \\
(\boldsymbol{\%})\end{array}$ \\
\hline Re-entry period & & & & & \\
& & & & & \\
$1-24 \mathrm{~h}$ & 2.8 & 3.3 & 0.0 & 0.0 & 1.5 \\
$24-72 \mathrm{~h}$ & 36.2 & 0.0 & 35.5 & 32.0 & 25.9 \\
$72-168 \mathrm{~h}$ & 11.1 & 26.7 & 22.6 & 28.0 & 22.1 \\
$>168 \mathrm{~h}$ & 19.4 & 3.3 & 3.2 & 18.0 & 11.0 \\
Any time & 30.5 & 66.7 & 38.7 & 22.0 & 39.5 \\
\hline
\end{tabular}

of such organisations were Abrabopa, Akuapa Kooko, Akuafo Adamfo, Akuafo boafo, and other locally organised groups.

About $16.7 \%, 26.7 \%, 26.7 \%$ and $42 \%$ of the respondents in the Ashanti, Eastern, Volta and Western regions respectively know about the three COCOBOD approved insecticides for insect pest management on cocoa. Some of the farmers use insecticides not recommended by COCOBOD and do 11 applications of these insecticides to their farms in a year in addition to the two they get from the mass spraying exercise. About $2.8 \%$ of the farmers in Ashanti and $3.3 \%$ in Eastern regions have little knowledge about the re-entry period of pesticides (Table 2). Re-entry period of a pesticide is the earliest time at which workers can re-enter agricultural fields safely without personal protective clothing or equipment since last pesticide application (US Environmental Protection Agency, 1996).

Among the farmers that owned spraying machines a little over half (i.e. 52.8\%) own motorizedmist blower which is the recommended equipment for insecticide application in cocoa farming. A sizeable number (i.e. 47.2\%) of the 
farmers use knapsack in the absence of a mistblower (Table 3). Some farmers (i.e. 44.8\%) do their own spray application whereas others (i.e. $55.2 \%$ ) hire labour (Table 4) to spray their farms.

A few (i.e. $31.6 \%$ ) of the respondents put on the full personal protective costume during insecticide application and $21.9 \%$ do not use any protection (Table 5). Full costume is a complete set of Personal Protective Equipment (PPE) required for spraying. This includes a hat, respirator, goggles, gloves, overall and Wellington boot. Partial costume is any of these and no costume is when farmers use their farming gear without an additional PPE. There was a positive correlation between farmers' membership in farmer-based organisation and the costume-wearing farmers in the Ashanti, East- ern and Volta Regions and it was significant in the Ashanti region (Table 6). About $60.9 \%$ of the population across the regions read the label on the insecticides before application (Table 7). This implies that these farmers are likely to be aware of the expiration date of the chemical before use.

Most farmers (59.3\%) dispose of the empty chemical containers on the farm after pesticide application (Table 8). There was a positive correlation between farmers' membership in farmer-based organisation and disposal of chemical containers in all the regions with significance recorded in the Ashanti and Volta Regions (Table 9).

\section{DISCUSSION}

It is evident from the results that males domi-

Table 3: Ownership of insecticide application equipment in four regions of Ghana

\begin{tabular}{lccccc}
\hline Variable & $\begin{array}{c}\text { Ashanti } \\
(\boldsymbol{\%})\end{array}$ & $\begin{array}{c}\text { Eastern } \\
(\mathbf{\%})\end{array}$ & $\begin{array}{c}\text { Volta } \\
(\boldsymbol{\%})\end{array}$ & $\begin{array}{c}\text { Western } \\
(\boldsymbol{\%})\end{array}$ & $\begin{array}{c}\text { Average } \\
(\boldsymbol{\%})\end{array}$ \\
\hline $\begin{array}{l}\text { Ownership of insecticide application } \\
\text { equipment (Motorised mist blower) }\end{array}$ & & & & & \\
Yes & & & & & \\
No & 16.7 & 73.3 & 61.3 & 60.0 & 52.8 \\
& 83.3 & 26.7 & 38.7 & 40.0 & 47.2 \\
\hline
\end{tabular}

Table 4: Pesticide application by farmers in four regions of Ghana

\begin{tabular}{lccccc}
\hline & Ashanti (\%) & Eastern (\%) & Volta (\%) & Western (\%) & Average (\%) \\
Variable & & & & & \\
\hline $\begin{array}{l}\text { Pesticide application by } \\
\text { farmers }\end{array}$ & & & & \\
Self & 27.8 & 33.3 & 74.2 & 44.0 & 44.8 \\
Hired labour & 72.2 & 66.7 & 25.8 & 56.0 & 55.2 \\
\hline
\end{tabular}


Insecticide handling by cocoa farmers...

5

Table 5: Dress code of farmers during chemical spraying application in four regions of Ghana

\begin{tabular}{lccccc}
\hline Variable & $\begin{array}{c}\text { Ashanti } \\
(\boldsymbol{\%})\end{array}$ & $\begin{array}{c}\text { Eastern } \\
(\boldsymbol{\%})\end{array}$ & $\begin{array}{c}\text { Volta } \\
(\boldsymbol{\%})\end{array}$ & $\begin{array}{c}\text { Western } \\
(\boldsymbol{\%})\end{array}$ & $\begin{array}{c}\text { Average } \\
(\boldsymbol{\%})\end{array}$ \\
\hline $\begin{array}{l}\text { Dress code during chemical } \\
\text { spraying application }\end{array}$ & & & & & \\
& & & & & \\
Full costume & 40.0 & 25.0 & 20.7 & 40.5 & 31.6 \\
Partial costume & 36.7 & 75.0 & 41.4 & 33.3 & 46.6 \\
No costume & 23.3 & 0.0 & 37.9 & 26.2 & 21.9 \\
\hline
\end{tabular}

Table 6: Correlation between membership in farmer-based organisation and farmers dress during spraying

\begin{tabular}{llllll}
\hline $\begin{array}{l}\text { Independent } \\
\text { Variable }\end{array}$ & $\begin{array}{l}\text { Dependent } \\
\text { Variable }\end{array}$ & Ashanti & Eastern & Volta & Western \\
\hline $\begin{array}{l}\text { Are you part of a } \\
\text { farmer organization }\end{array}$ & $\begin{array}{l}\text { If yes, then how do you } \\
\text { dress when spraying }\end{array}$ & $0.553^{*}$ & 0.323 & 0.362 & -0.078 \\
\hline
\end{tabular}

*significant at $p<0.01$

Table 7: The response of farmers in four regions of Ghana on their knowledge of expiration date of pesticides

\begin{tabular}{lccccc}
\hline Variable & $\begin{array}{c}\text { Ashanti } \\
(\boldsymbol{\%})\end{array}$ & $\begin{array}{c}\text { Eastern } \\
(\boldsymbol{\%})\end{array}$ & $\begin{array}{c}\text { Volta } \\
(\boldsymbol{\%})\end{array}$ & $\begin{array}{c}\text { Western } \\
(\boldsymbol{\%})\end{array}$ & $\begin{array}{c}\text { Average } \\
(\boldsymbol{\%})\end{array}$ \\
\hline $\begin{array}{l}\text { Farmers response on their } \\
\text { knowledge of expiration } \\
\text { date of pesticides }\end{array}$ & & & & \\
& & & & & \\
Yes & 54.3 & 53.3 & 73.3 & 62.5 & 60.9 \\
No & 45.7 & 46.7 & 26.7 & 37.5 & 39.1 \\
\hline
\end{tabular}

nate cocoa farming. This can be attributed to the fact that cocoa farming is labour intensive. It was observed that cocoa farmers in the study areas were comparatively old. In recent times, the youth are not interested in agriculture because it is not lucrative and appealing enough.
The government's introduction of the Youth in Agriculture Programme (YIAP) was aimed at responding to that and also facilitating sustainability in agriculture production (MoFA, 2011). The farmers have been in cocoa production for years and this has helped them gain experience 
Antwi-Agyakwa et al.

Table 8: Disposal of chemical containers after chemical by farmers in four regions of Ghana

\begin{tabular}{lcrrrr}
\hline Variable & $\begin{array}{c}\text { Ashanti } \\
(\boldsymbol{\%})\end{array}$ & $\begin{array}{c}\text { Eastern } \\
(\boldsymbol{\%})\end{array}$ & $\begin{array}{c}\text { Volta } \\
(\boldsymbol{\%})\end{array}$ & $\begin{array}{c}\text { Western } \\
(\boldsymbol{\%})\end{array}$ & $\begin{array}{c}\text { Average } \\
(\boldsymbol{\%})\end{array}$ \\
\hline Disposal of chemical containers & & & & & \\
& & & & & \\
Throw away on farm & 61.1 & 40.0 & 58.0 & 78.0 & 59.3 \\
Bury in ground on farm & 13.9 & 30.0 & 25.8 & 4.0 & 18.4 \\
Burn & 13.9 & 23.3 & 6.5 & 10.0 & 13.4 \\
Carry it away & 11.1 & 6.7 & 0.0 & 8.0 & 6.5 \\
Dispose at refuse damp & 0.0 & 0.0 & 9.7 & 0.0 & 2.4 \\
\hline
\end{tabular}

Table 9 : Correlation between how farmers discard empty chemical containers and their membership in farmer-based organization

\begin{tabular}{|c|c|c|c|c|c|}
\hline \multirow{2}{*}{$\begin{array}{l}\text { Independent } \\
\text { variable }\end{array}$} & \multirow{2}{*}{$\begin{array}{l}\text { Dependent } \\
\text { Variable }\end{array}$} & \multirow[b]{2}{*}{ Ashanti } & \multicolumn{3}{|c|}{ Pearson Correlation (r) } \\
\hline & & & Eastern & Volta & Western \\
\hline $\begin{array}{l}\text { Are you part of a } \\
\text { farmer organisation }\end{array}$ & $\begin{array}{l}\text { how do you discard empty } \\
\text { chemical containers }\end{array}$ & $0.439 *$ & 0.254 & $0.597 *$ & 0.044 \\
\hline
\end{tabular}

* significant at $p<0.05$

in the practices that work well. Formal education makes farmers more open and willing to adopt new ideas and cocoa production methods. Generally, most of the farmers in the study areas may be considered semi-literates and may be operating on the assumption that one does not need formal education to do farming. This confirms a report from MoFA (2011) that Ghanaians negatively perceive farming to be for the uneducated and unskilled people. The welleducated families usually look elsewhere for other jobs. The few that go into farming consider the profession as a hobby and perhaps go into it a few years to retirement.

Farmer-based organisations are formal collective action groups of farmers with an aim of achieving common interest (Hellin et al., 2007). They serve as means by which farmers get education on proper agricultural practices as well as learn new methods in farming. Some of the farmers who were members of identifiable groups indicated that it has been helpful in terms of education, market access, loans and materials needed for managing their farms. One farmer confirmed that a year after joining one of these organisations, his yield drastically increased from 16 bags to 36 bags from one hectare and has since been increasing. Despite the enormous benefits of being a member of an organisation, a major challenge is cost. Stockbridge et al. (2003) observed that farmer organizations incur transaction costs which, if too high, may put financial burden on its members, with the effect of discouraging other farmers from joining. Farmers should be encouraged to join these organisations because being a member enhances a farmer's tendency of learning new things and these farmers are also easily identified in the society. Farmers also are involved in healthy competition and strive to do their best to improve on their productivity. 
Cocoa farmers are expected to do about four spray applications in a year and are entitled to two spray applications under the CODAPEC exercise (Asare, 2011). Farmers are therefore expected to do the other two applications. Lack of knowledge of the COCOBOD recommended insecticides and the recommendations for application can result in misuse and misapplication of pesticides. Some farmers do more than four insecticide applications in a year, implying that some farmers are applying insecticides over and above the recommendations and this could lead to negative consequences including undesirable chemical residues (data not shown) in harvested cocoa beans as well as pesticide resistance and pest resurgence.

Observance of the entry period of chemicals is an important concept under pesticide handling to avoid contamination and to be safe from pesticide effect. Most farmers are not aware of the re-entry period and therefore visit the farm to carry out agronomic activities such as weeding and pruning and other activities with respect to the other food crops they grow. It is important to educate farmers on the dangers involved in poor handling of insecticides and the strict adherence of the re-entry period to avoid or reduce pesticide toxicity. Pesticides have been one of the most important occupational hazards among farmers in developing countries (Coronado et al., 2004). Therefore it is important that farmers pay particular attention to the handling of these chemicals so as to enjoy maximum benefit and escape their hazardous effects as much as possible.

The motorised mistblower is suitable for aerial spraying over large areas. It produces a high velocity air stream which is discharged through the hose as droplets (Pal and Das Gupta, 1996), whereas a knapsack does not. This makes the mistblower more effective than a knapsack in the application of insecticides for the control of mirids.

Some farmers do spraying without wearing personal protective equipment (PPE). Most farmers complained of the cost of acquiring these protective clothing. This confirms findings by Ntow et al. (2006) that the use of PPE by Ghanaian farmers during mixing, loading and application of pesticides is low mainly because of financial difficulties. Other farmers stated that they feel uncomfortable in the use of these wears in addition to interference with work. Attention must be paid to PPE because it helps protect farmers from pesticide poisoning. It is stated in the Pesticide Control and Management Act of the Laws of Ghana that no person should use pesticides without PPE (Ghana Laws, 2014). But this law has been totally ignored. According to WHO (2004), 1 to 5 million cases of pesticide poisoning occur every year, resulting in 20,000 fatalities among agricultural workers, most of them in developing countries including Ghana. Another estimate is that pesticides misuse cause $14 \%$ of all known occupational injuries in agriculture and $10 \%$ of all fatal injuries (Oppong-Wereko, 2013).

The fact that most farmers indicate little knowledge about the expiration date of insecticides presupposes that often they do not read the label on the container. Labels on chemical containers contain important information which includes the best way a chemical can be used to attain desirable results, the way to dispose of the container and excess chemical solution. From the results gathered, it can be inferred that literate farmers read the labels whereas illiterate farmers do not read. Some of these farmers might have used expired chemicals without even knowing it. This may explain why some farmers do not remember the names of the chemicals they have used or are using. Farmers must be encouraged to read the labels in order to avoid the use of expired chemicals and this calls for the intensification of education on safe handling and use of pesticides.

Farmers in the study areas mostly dispose of empty chemical containers on the field which may cause adverse effects on soil flora and fauna. Ntow et al. (2006) also reported that throwing of containers on the field is the most common practice and method Ghanaian farm- 
ers adopt in disposing of empty chemical containers. The Environmental Health Manual (2010) identifies the community rubbish dump as the best place to discard empty pesticide containers after the containers have been triple washed with the appropriate solvent. The Manual again warned against the burning of pesticide containers because they can give off poisonous gases. It is unfortunate that most farmers in Ghana do not attach much importance to the handling and disposal of chemical containers.

\section{CONCLUSION}

Males dominate cocoa production in Ghana. Farmers use Ghana COCOBOD recommended pesticides and others sold on the open market. Most farmers do their own spray application with some having their own spraying machines. Very few farmers wear full costume during spray application and very few observe the restricted entry interval of the insecticides. Farmers need more education on pesticide use practices so it behoves on the government, nongovernmental agencies and individuals to help train farmers on safe pesticide handling and use.

\section{ACKNOWLEDGEMENT}

The authors are grateful to the cocoa farmers and the agricultural extension officers in the areas visited for assisting in sampling and the provision of information for the project. We are grateful to CHEMICO Ghana and Cocoa Research Institute of Ghana for the logistics support.

\section{REFERENCES}

Adu-Acheampong, R., Padi, B., Ackonor, J. B., Adu-Ampomah, Y. and Opoku, I. Y. (2007). Field Performance of Some Local and International Clones of Cocoa against Infestation by Mirids. In: Global Approaches to Cocoa Germplasm Utilisation and Conservation: A Final Report of the CFC/ICCO/IPGRI Project on Cocoa Germplasm Utilisation and Conservation: A global approach, 19982004.
Anim-Kwapong, G. J. and Frimpong, E. B. (2006). Vulnerability and adaptation assessment under the Netherlands climate change assistance programme. Phase 2 (NCAP2): Vulnerability of agriculture to climate change - impact of climate on cocoa production. Final report submitted to Environmental Protection Agency, Ghana.

Asare, E. (2011). Modelling cocoa farmer behaviour concerning the chemical control of capsid in the Sekyere area of Ashanti Region, Ghana. MPhil. Thesis, Kwame Nkrumah University of Science and Technology, Kumasi, Ghana.

Coronado, G. D., Thompson, B., Strong, L., Griffith, W. C. and Islas, I. (2004). Agricultural Task and Exposure to Organophosphate Pesticides among Farm Workers. Environmental Health Perspectives, 18: 142-147.

Dormon, E. N. A., Van Huis, A. and Leeuwis, C. (2007). Effectiveness and profitability of pest management for improving yield on small holder cocoa farms in Ghana. International Journal of Tropical Insect Science, 27 (1): $27-39$.

Dudgeon, G. C. (1910). Notes on two West African Hemiptera injurious to Cocoa. Bulletin of Entomological Research, 1: 59-61.

Environmental Health Manual. (2010). Disposal of unused pesticides and empty pesticide container. Available online at www.health.gov.au/internet/publications/ publishing.nsf/content/ohp-enhealth-manualatsi-cnt-i-ch5. Accessed on 20th July, 2013.

Ghana Laws. (2014). Pesticides Control and Management Act. Globalization. London, UK: ITDG Publishing and Latin American Bureau.

Hellin, J., Lundy, M. and Meijer, M. (2007). Farmer Organization, Collective Action and Market Access in Meso-America. CAPRi 
working paper No. 67, 28 pp.

MoFA (Ministry of Food and Agriculture). (2011). Youth in Agriculture; Programme Policy, Strategy and Sustainability. Available online at: www.mofa.gov.gh. Accessed on 16th August, 2013.

Ntow, W. J., Gijzen, H. J., Kelderman, P. and Dreschsel, P. (2006). Farmers Perception and Pesticide Use Practices in Vegetable Production in Ghana. Pest Management Science, 62: 356- 365 .

Oppong-Wereko, D. (2013). REPORT: New policy to mitigate unsafe use of pesticides. http://graphic.com.gh/archive/General-News/ new-policy-to-mitigate-unsafe-use-ofpesticides.html. Accessed on $10^{\text {th }}$ April, 2014.

Padi, B., Ackunor, J. B., Opoku, I. Y., Hall, D., Farman, D., Downham, Odour, G., Lower, S., Owusu-Manu, E., Adu-Ampomah, Y., Sarfo, J. E., Adu-Acheampong, R., Reich, I. and Adusei, E. O. (2001). Recent advances in the development of integrated pest management strategy for the control of cocoa mirids and mealybug vectors of the cocoa swollen shoot virus disease in Ghana. In: proceedings of INCOPED $3^{\text {rd }}$ International cocoa pests

\section{Insecticide handling by cocoa farmers... 9}

and diseases seminar, 2000. Kota Kinabalu, Sabah, Malaysia. Pp. 114-122.

Pal, S. K. and Das Gupta, S. K. (1996). Skill Development Series No. 17. ICRISAT Training and Fellowship Programme. Available online at http://www.icrisat.org/what-we-do/ learning-opportunities/lsu-pdfs/sds.17.pdf. Accessed on 20th July, 2013.

Stockbridge, M., Dorward, A. and Kydd, J. (2003). Farmer organizations for market access: A briefing paper. Wye Campus, Kent, England: Imperial College, London.

US EPA (1996). Occupational and Residential Exposure Test Guidelines OPPTS 875.2000. Background for Post application Exposure Monitoring Test Guidelines. United States Environmental Protection Agency Prevention, Pesticides and Toxic Substances (7101) EPA 712-C-96-266 February 1996. Accessed on $15^{\text {th }}$ May, 2013 from http:// n e p is . e pa.gov/Ex e/Z y P D F.c gi/ P100G6W8.PDF?Dockey=P100G6W8.PDF

WHO (2004). Childhood Pesticide Poisoning: Information for advocacy and action. Published by the Chemicals Programme of the United Nations Environment Programme (UNEP Chemicals). pp 37 